\title{
Analisis Efektivitas Dana Zakat dalam Peningkatan Pendapatan Usaha Mustahik di Kabupaten Padang Lawas
}

\author{
Jogina Santi Siregar¹, Delima Sari Lubis ${ }^{2}$, Rini Hayati Lubis ${ }^{3}$ \\ 1,2,Institut Agama Islam Negeri Padangsidimpuan \\ JL. H.T. Rizal Nurdin Km 4,5 Sihitang Kota Padangsidimpuan__Sumatera Utara \\ joginasanti19@gmail.com,delimasari@iain-padangsidimpuan.ac.id², \\ rinihayati@iain-padangsidimpuan.ac.id 3
}

\begin{abstract}
BAZNAS Padang Lawas Regency has distributed productive zakat funds to mustahiq and utilized zakat for business capital, but productive zakat funds have not been effective in increasing mustahiq's business income. This study aims to determine how the distribution of productive zakat funds, the utilization of productive zakat funds and the effectiveness of zakat funds in increasing mustahiq business income in Padang Lawas Regency. This study uses a descriptive qualitative approach with field research (field research). The results of this study indicate that economic development in increasing mustahiq business income in Padang Lawas Regency has not been effective in its implementation, from the four indicators used, namely targeting accuracy, program socialization, program monitoring and program objectives. Only indicators of target accuracy have been effective. This is due to poor monitoring from BAZNAS and non-existent assistance, lack of human resources, lack of mustahiq knowledge about zakat utilization and mustahik's lack of responsibility in managing their business after being given productive zakat funds.
\end{abstract}

Keywords : Productive Zakat, Effectiveness, Mustahiq

\begin{abstract}
ABSTRAK
BAZNAS Kabupaten Padang Lawas sudah menyalurkan dana zakat produktif kepada mustahik dan mendayagunakan zakat untuk modal usaha namun dana zakat produktif belum efektif dalam peningkatan pendapatan usaha mustahik. Penelitian ini bertujuan untuk mengetahui bagaimana penyaluran dana zakat produktif, pendayagunaan dana zakat produktif dan efektivitas dana zakat dalam peningkatan pendapatan usaha mustahik di Kabupaten Padang Lawas. Penelitian ini menggunakan pendekatan kualitatif deskriptif dengan penelitian lapangan (field Reseach). Hasil penelitian ini menunjukkan pengembangan ekonomi dalam peningkatan pendapatan usaha mustahik di Kabupaten Padang Lawas dalam pelaksanaannya belum efektif, dari empat indikator yang digunakan yaitu ketepatan sasaran, sosialisasi program, pemantauan program dan tujuan program. Hanya indikator ketepatan sasaran yang sudah efektif. Hal ini disebabkan pemantauan dari pihak BAZNAS yang kurang lancar serta pendampingan yang tidak ada, sumber daya manusia yang kurang, pengetahuan mustahik yang kurang tentang pemanfaatan zakat dan kurangnya tanggung jawab mustahik dalam mengelola usahanya setelah diberikan dana zakat produktif.
\end{abstract}

Kata Kunci : Zakat Produktif, Efektivitas, Mustahik 
211 Analisis Efektivitas Dana Zakat dalam Peningkatan Pendapatan Usaha Mustahik di Kabupaten Padang Lawas

\section{PENDAHULUAN}

Keberadaan Indonesia sebagai negara berkembang tidak dapat lepas dari banyaknya permasalahan dibidang ekonomi. Salah satu permasalahan nyata yang dihadapi bangsa Indonesia adalah ketimpangan distribusi pendapatan dan kemiskinan (Hendri widia Astuti, 2019). Salah satu cara mengatasi kemiskinan adalah dukungan orang yang mampu mengeluarkan harta kekayaan mereka, berupa zakat kepada mereka yang kekurangan. Zakat merupakan salah satu dari lima nilai instrumental yang strategis dan sangat berpengaruh pada tingkah laku ekonomi manusia dan masyarakat serta pembangunan ekonomi umumnya (Asma karimah, 2017). Dewasa ini zakat menjadi hal penting untuk diperhatikan karena zakat merupakan salah satu instrumen dalam ekonomi Islam, yang mampu mengurangi gejolak akibat problematika kesenjangan dalam hidup. Agar dana zakat yang disalurkan kepada orang miskin dapat berdaya guna, maka pemanfaatannya harus efektif.

Keefektifan dalam organisasi sangat diperlukan, terutama dalam pengelolaan zakat di Badan Amil Zakat Nasional (BAZNAS). Dalam suatu organisasi, terutama BAZNAS harus memperhatikan efektivitas sepanjang waktu dan berkinerja secara efektif (Hani Handoko,2003). Efektivitas adalah kemampuan memilih tujuan yang tepat untuk pencapaian tujuan yang telah diputuskan, dengan kata lain program yang efektif memberikan kebijakan yang harus dilakukan serta metode yang tepat untuk mencapai tujuan yang telah ditetapkan. Dari penjelasan tersebut dapat ditarik kesimpulan efektivitas merupakan suatu kemampuan untuk memilih tujuan yang tepat terhadap tujuan yang telah ditetapkan. Di samping itu untuk mengetahui lebih jelas tentang zakat. Zakat adalah kadar harta yang wajib dikeluarkan dan telah ditetapkan Allah SWT kepada setiap muslim yang mampu untuk mencapai keridhaan Allah SWT, berfungsi untuk membersihkan jiwa orang yang berzakat dan membebaskan beban orang yang membutuhkannya (Abdul Rasyid MZ, 2019).

Zakat produktif adalah penggabungan kata zakat dan produktif mempunyai arti bahwa zakat yang dalam pendistribusiannya dilakukan dengan cara produktif, atau dengan kata lain tujuan pendistribusian zakat tersebut yaitu untuk diproduktifkan dengan 
cara pendistribusian yang tepat guna dan manfaatnya dengan sistem serba guna, model pendistribusian zakat yang dapat membuat para mustahik menghasilkan sesuatu secara terus menerus dan meningkatkan pendapatan usaha mereka, dengan harta zakat yang diterimanya. Singkatnya zakat produktif adalah harta zakat yang diberikan kepada mustahik untuk tidak dihabiskan atau di konsumsi akan tetapi digunakan untuk dikembangkan dalam rangka membantu usaha mereka, sehingga dengan usaha tersebut para penerimanya dapat memenuhi kebutuhan hidupnya secara terus menerus dan pendapatan usahanya meningkat, bahkan bisa berubah status dari mustahik menjadi muzakki.

Di Indonesia saat ini memakai UU No. 38 tahun 2011 dalam pengelolaan dana zakat yang sebelumnya memakai UU No. 23 tahun 1999. Penyaluran dana zakat secara produktif berarti memberikan zakat kepada mustahik untuk dijadikan modal usaha yang menjadi mata pencaharian mereka dengan usaha ini akan mampu meningkatkan pendapatan dan bisa memenuhi kebutuhan mereka sehari-hari (Marwiyah Ulfa, 2019).

Badan Amil Zakat Nasional (BAZNAS) Kabupaten Padang Lawas sebagai lembaga amil zakat yang bergerak di bidang sosial dan keagamaan yang memiliki peranan untuk mengembangkan ekonomi, keagamaan, pendidikan, advokasi (dakwah) dan kesehatan. Termasuk dibidang pemberdayaan ekonomi rakyat kecil dan menengah serta pengembangan ekonomi kerakyataan di wilayah Kabupaten Padang Lawas dengan memberikan dana zakat produktif sebagai modal usaha.

Zakat produktif yang disalurkan di Baznas Kabupaten padang Lawas melalui pemberdayaan ekonomi umat melalui pinjaman (dana Bergulir) dan pinjaman modal usaha yang diberikan secara resmi tanpa ada tuntutan untuk mengembalikan dana tersebut kepada BAZNAS. Oleh karena itu si mustahik akan menganggap dana yang diberikan seperti zakat konsumtif dan akan menyebabkan si penerima tidak akan bersungguhsungguh dalam menjalankan usahanya (wawancara dengan Bapak Abdul Haris selaku Ketua BAZNAS Kabupaten Padang Lawas). Berikut ini data mustahik yang menerima dana zakat produkti pada tahun 2019-2021. 
213 | Analisis Efektivitas Dana Zakat dalam Peningkatan Pendapatan Usaha Mustahik di Kabupaten Padang Lawas

Tabel 1. Data pendapatan Mustahik sebelum dan sesudah Menerima dana zakat produktif 2019-2021

\begin{tabular}{|c|c|c|c|c|c|}
\hline Nama & $\begin{array}{l}\text { Jenis } \\
\text { usaha }\end{array}$ & $\begin{array}{c}\text { Modal sebelum } \\
\text { menerima }\end{array}$ & $\begin{array}{c}\text { Modal } \\
\text { setelah } \\
\text { menerima }\end{array}$ & $\begin{array}{c}\text { Keuntunga } \\
\text { n sebelum } \\
\text { menerima } \\
\text { (Hari) }\end{array}$ & $\begin{array}{c}\text { Keuntunga } \\
\text { n setelah } \\
\text { menerima } \\
\text { (Hari) }\end{array}$ \\
\hline $\begin{array}{l}\text { Ibu Samra } \\
\text { Hasibuan }\end{array}$ & $\begin{array}{l}\text { Lopo } \\
\text { Kopi }\end{array}$ & Rp. 2.000 .000 & Rp. 5.000 .000 & Rp. 60.000 & Rp. 100.000 \\
\hline $\begin{array}{l}\text { Pak Ali } \\
\text { Imran }\end{array}$ & $\begin{array}{l}\text { Tambal } \\
\text { Ban }\end{array}$ & Rp. 2.500 .000 & Rp. 4.000 .000 & Rp. 40.000 & Rp. 70.000 \\
\hline Ibu Ningsih & $\begin{array}{l}\text { Jualan } \\
\text { Sayur }\end{array}$ & Rp. 1.000.000 & Rp. 2.500 .000 & Rp. 50.000 & Rp. 60.000 \\
\hline $\begin{array}{l}\text { Bapak } \\
\text { mayuddin }\end{array}$ & $\begin{array}{l}\text { Bengkel } \\
\text { motor }\end{array}$ & Rp. 6.000 .000 & Rp. 3000.000 & Rp. 200.000 & Rp. 200.000 \\
\hline Ibu Nur & Jual Ikan & Rp. 300.000 & Rp. 600.00 & - & - \\
\hline Ibu Belina & Jual kue & Rp. 1.000 .000 & Rp. 2.500 .000 & $\operatorname{Rp} 40.000$ & Rp.40.000 \\
\hline Ibu Pinta Ito & $\begin{array}{l}\text { Jual } \\
\text { jajanan }\end{array}$ & Rp. 2.000 .000 & Rp. 3.500 .000 & - & - \\
\hline $\begin{array}{l}\text { Ibu Minta } \\
\text { Manarida }\end{array}$ & $\begin{array}{l}\text { Jual } \\
\text { gorengan }\end{array}$ & Rp. 300.000 & Rp. 600.000 & Rp. 50.000 & Rp.50.000 \\
\hline Ibu Mawar & $\begin{array}{l}\text { Jual } \\
\text { jajanan }\end{array}$ & Rp. 2.500 .000 & Rp. 3.500 .000 & Rp._ & - \\
\hline
\end{tabular}

Sumber : Wawancara dengan Mustahik

Berdasarkan tabel diatas dapat disimpulkan bahwa tidak semua usaha mengalami peningkatan. Dari Sembilan (9) mustahik hanya empat (4) yang mengalami peningkatan. Hal tersebut yang disebabkan oleh tidak adanya pemisahan antara uang pribadi dengan uang penjualan, sehingga omzet penjualan usaha tidak terlihat peningkatannya dan sumber daya manusia juga kurang memadai. Sedangkan mustahik mustahik yang tidak mengalami peningkatan sama sekali sebanyak tiga (3) mustahik. Hal tersebut disebabkan oleh dana zakat yang diperoleh cenderung digunakan untuk keperluan konsumtif, seperti http://jurnal.iain-padangsidimpuan.ac.id/index.php/JISFIM 
untuk membayar utang, biaya sekolah dan lain-lain. Permasalahan lain yang dialami oleh para mustahik adalah persaingan usaha yang ketat, kurangnya sklill dalam mengelola usaha, dan kurangnya pemahaman mustahik terhadap pemanfaatan zakat produktif sehingga mendorong mustahik untuk menggunakan zakat produktif sebagai zakat konsumtif, yang akibatnya usaha dan pendapatan mereka tidak mengalami peningkatan. Berdasarkan latarbelakang tersebut maka penulis tertarik untuk melakukan penelitian yang berjudul “Analisis Efektivitas Dana Zakat dalam Peningkatan Pendapatan Usaha Mustahik di BAZNAS Kabupaten Padang Lawas.

\section{METODE PENELITIAN}

Jenis penelitian dalam penelitian ini adalah dengan menggunakan jenis penelitian lapangan dengan pendekatan deskriptif kualitatif. Penelitian ini berlokasi di BAZNAS Kabupaten Padang Lawas yang terletak di Jl.KH. Dewantara Pasar Sibuhuan Padang Lawas Sumatera Utara yang dimulai dari April sampai dengan Desember 2021. Sumber data dalam penelitian ada dua yaitu: primer berupa informan yaitu Ketua BAZNAS kabupaten Padang Lawas, Bendahara BAZNAS kabupaten Padang Lawas dan penerima bantuan zakat produktif sebagai modal usaha. Sedangkan data Sekunder berupa laporan pertanggungjawaban pimpinan BAZNAS Kabupaten Padang lawas pada tahun 20192021.

Teknik pengumpulan data dilakukan dengan 3 cara yaitu, wawancara, observasi dan dokumentasi. Setelah data-data terkumpun maka peneliti mengolahnya dengan mengadakan analisis dengan beberapa tahap yaitu; 1) pengumpulan data yaitu dilakukan pada saat wawancara sedang berlangsung; 2) reduksi data yang merupakan penyederhanaan terhadap klasifikasi data dan kemudian mengelompokkan masingmasing data. Dalam hal ini peneliti memfokuskan pada penyaluran dan pendayagunaan zakat; 3) penyajian data, pada langkah ini peneliti berusaha menyusun data yang relevan sehingga menjadi informan yang dapat disimpulkan, dimana prosesnya dapat dilakukan dengan cara menampilkan data, membuat hubungan antar fenomena untuk memaknai apa 
215 | Analisis Efektivitas Dana Zakat dalam Peningkatan Pendapatan Usaha Mustahik di Kabupaten Padang Lawas

yang sebenarnya terjadi dan apa yang perlu ditindaklanjuti untuk mencapai tujuan penelitian dan; 4) penarikan kesimpulan dimana pada tahap ini peneliti melakukan penarikan kesimpulan.

Teknik pengecekan keabsahan data dalam penelitian ini ialah menggunakan triangulasi sumber dilakukan dengan membandingkan kepercayaan suatu informasi yang diperoleh melalui waktu dan cara yang berbeda dari berbagai sumber yang di dapatkan, dan triangulasi metode Triangulasi metode dilakukan pengecekan ulang dengan metode lain untuk membandingkan keabsahan data. Apakah data yang diperoleh dari observasi dan wawancara mempunyai persamaan atau perbedaan.

\section{HASIL DAN PEMBAHASAN}

\section{Pengertian Zakat produktif}

Zakat berasal dari bahasa arab yaitu "zakka-yuzakki-tazkiyatan-zakatan" yang memiliki arti bersih, tumbuh, atau amal sholeh (Fakhruddin, 2008). Sedangkan secara terminology zakat adalah sejumlah harta tertentu yang telah mencapai syarat tertentu yang diwajibkan oleh allah untuk dikeluarkan dan diberikan kepada yang berhak menerimanya dengan persyaratan tertentu pula. Sedangkan kata produktif berasal dari bahasa inggirs yaitu "productive" yang artinya banyak mengahasilkan, menghasilkan banyak hasil, menghasilkan banyak barang-barang berharga, yang memberikan banyak hasil. Jadi zakat produktif adalah pemberian zakat yang mampu membuat penerimanya menghasilkan secara terus menerus dengan zakat yang telah diberikan. Dengan demikian zakat produktif adalah zakat yang dimana harta zakat dimanfaatkan dalam satu waktu akan tetapi digunakan untuk waktu yang berkepanjangan sehingga hasilnya bisa dinikmati terus menerus.

\section{Penyaluran Zakat Produktif}

Peranan zakat bukanlah sekedar memberikan beberapa uang atau beberapa liter beras yang cukup untuk menghidupi seorang penerima zakat dalam beberapa hari atau beberapa minggu, setelah itu ia akan kembali kepada kondisi semula dan mengulurkan 
tangannya menerima bantuan zakat. Sebenarnya peranan zakat itu terletak bagaimana seorang penerima mampu menghidupi dirinya sendiri dengan kemampuan yang dimilikinya, dan memiliki penghasilan tetap yang mencukupi kehidupannya, sehingga ia tidak perlu bergantung kepada bantuan orang lain (Yusuf Qardhawi, 2005). Salah satu fungsi zakat adalah fungsi sosial, yaitu sarana bersosialisasi antara orang kaya dan orang miskin agar dana zakat yang disalurkan dapat berdaya guna dan berhasil guna, maka dalam pemanfaatannya harus selektif. Dalam distribusi dana zakat setidaknya ada dua model distribusi yaitu bentuk sesaat dan bentuk pemberdayaan.

\section{Pendayagunaan Zakat Produktif}

Menurut Kamus Besar Bahasa Indonesia (KBBI) "pendayagunaan berasal dari kata daya guna yang bermakna kemampuan mendatangkan hasil dan manfaat, efisen, tepat guna". Sedangkan pendayagunaan sendiri berarti: mengusahakan agar mampu mendatangkan hasil dan manfaat mengusahakan agar mampu menjalankan tugas dengan baik. Pendayagunaan zakat erat kaitannya dengan bagaimana cara pendistribusiannya. Kondisi ini dikarenakan jika pendistribusiannya tapat guna dan tepat sasaran, maka pendayagunaan zakat akan lebih optimal (Gesy Evelin, 2018). Dalam undang-undang No. 23 tahun 2011 tentang pengelolaan zakat, dijelaskan mengenai pendayagunaan zakat yaitu ; Zakat dapat didayagunakan untuk usaha produktif dalam rangka penanganan fakir miskin dan peningkatan kualitas umat; Pendayagunaan zakat untuk usaha produktif sebagaimana dimaksud pada ayat (1) dilakukan apabila kebutuhan dasar mustahik telah terpenuhi.

\section{Peningkatan Pendapatan}

Sebagai Badan Amil Zakat yang membawahi seluruh BAZNAS yang di Kabupaten Padang Lawas, maka Baznas Kabupaten Padang Lawas senantiasa menyalurkan bantuan kepada para mustahik yang ebrhak menerimanya secara langsung dengan tujuan mampu membantu peningkatan perekonomian masyarakat Kabupaten Padang Lawas. 
217 | Analisis Efektivitas Dana Zakat dalam Peningkatan Pendapatan Usaha Mustahik di Kabupaten Padang Lawas

\section{Efektivitas}

Secara sederhana efektivitas dapat dipahami sebagai tingkat keberhasilan suatu kebijakan atau program dalam usahanya untuk mencapai tujuan sesuai dengan perencanaan yang diinginkan sehingga menghasilkan hasil dan dampak sesuai harapan (Hanif Ardiansyah, 2014). Efektivitas sering dikaitkan dengan efisiensi, akan tetapi efektivitas memiliki makna yang berbeda dengan efisiensi. (Rai, 2008) menjelaskan bahwa efektivitas mengacu pada hubungan antara output dengan tujuan yang ditetapkan. Suatu organisasi, program, atau kegiatan dikatakan efektif jika output yang dihasilkan dapat memenuhi tujuaan yang ditetapkan. Untuk mengukur efektivitas suatu program dapat dilakukan denggan menggunakan variabel berikut: 1. Ketepatan sasaran program, 2. Sosialisasi program, 3. Pemantauan program, 4. Tujuan program, Prinsip efektivitas merupakan asas terpenting yang harus dilaksanakan oleh berbagai lembaga, tidak terkecuali lembaga non profit seperti lembaga zakat (Budiani dalam khadafi, 2017). Tujuannya agar lembaga dapat mengatahui sejauh mana fungsi dari program yang dilaksanakan telah bermanfaat untuk masyarakat. Prinsip tersebut juga sangat dibutuhkan sebagai upaya evaluasi dalam rangka mengoptimalkan peran lembaga zakat. Harapannya agar kinerja lembaga zakat tetap berjalan secara profesional dan tetap menjunjung tinggi nilai-nilai Islam (Ningrum, 2016).

\section{Penyaluran Dana zakat produktif di BAZNAS Kabupaten Padang Lawas}

Penyaluran dana zakat produktif di BAZNAS Kabupaten Padang Lawas dilakukan melalui beberapa tahapan yaitu:

\section{a. Perencanaan}

Perencanaan pendisitribusian zakat di BAZNAS Kabupaten Padang Lawas diberikan berdasarkan permohonan dari pihak eksternal (mustahik) baik individu maupun kelompok, melihat dari kondisi atau kebutuhan masyarakat itu sendiri. Dana zakat yang disalurkan di BAZNAS Kabupaten Padang lawas dominan kepada masyarakat fakir dan miskin. 
b. Organizing (Pengorganisasian)

Apabila perencanaan telah dilaksanakan, maka selanjutnya adalah pengorganisasian. Dalam pengorganisasian untuk menjadi seorang mustahik harus melewati beberapa prosedur yaitu berupa foto copy KTP, KK, Surat Keterangan Kurang Mampu dari Kepala Desa atau Lurah Setempat dan dokumen pendukung lainnya. Selain itu mustahik juga harus menyiapkan surat pernyataan bersedia mengikuti peraturan dari BAZNAS kabupaten Padang Lawas. Setelah persyaratan-persyaratan tersebut telah disiapkan maka BAZNAS akan melakukan survey langsung kelokasi usaha untuk memastikan bahwa berkas-berkas yang diberikan si calon mustahik ini benar. Setelah survey dilaksanakan pihak Baznas akan melakukan rapat dengan pimpinan untuk memastikan apakah si calon mustahik layak diberikan dana zakat produktif atau tidak.

c. Actuating (Penggerakan)

Setelah organizing dilakukan, maka selanjutnya adalah pelaksanaannya yaitu dengan memberikan dana zakat kepada mustahik. Dana zakat produktif yang digunakan untuk peningkatan pendapatan ialah melalui program ekonomi. Dimana program ekonomi ini ialah pemberian pinjaman modal usaha (Dana bergulir) dan bantuan modal usaha untuk si penerima agar penerima bantuan ini dapat meningkatkan usahanya dan memenuhi kebutuhannya secara terus menerus.

d. Pengawasan

Proses pengawasan penyaluran dana zakat produktif di BAZNAS Kabupaten Padang Lawas melalui monitoring dan evaluation sebulan sekali. BAZNAS kabupaten Padang Lawas bekerja sama dengan pemerintah daerah dalam melaksanakan pengawasan terhadap mustahik. Proses pengawasannya pun hanya dalam bentuk memberikan motivasi saja bukan mendatangkan ahli pada usaha si mustahik dan dalam pengawasannya tidak semua usaha mustahik dilakukan pengawasan yang disebabkan karena keterbatasan SDM (Sumber Daya Manusia) dan tidak adanya anggaran untuk melakukan pendampingan ataupun pengawasan. 
219 | Analisis Efektivitas Dana Zakat dalam Peningkatan Pendapatan Usaha Mustahik di Kabupaten Padang Lawas

\section{Pendayagunaan Zakat Produktif}

Konsep pendayagunaan dana zakat produktif di BAZNAS kabupaten Padang Lawas ialah produktif kreatif. Dimana produktif kreatif adalah memberikan modal dana bergulir dan bantuan modal usaha kepada mustahik untuk dikelola sendiri dalam mengembangkan usahanya. Tujuannya adalah untuk pemberdayaan ekonomi masyarakat terutamanya dalam peningkatan pendapatan, sehingga terwujudnya masyarakat maju, sejahtera dan mubarokah.

Pendayagunaan dana zakat produktif di BAZNAS Kabupaten Padang lawas di awali dengan pemberian zakat produktif dana bergulir dan bantuan modal usaha. Sebagaimana wawancara dengan ketua BAZNAS Kabupaten Padang Lawas

Dana zakat produktif didayagunakan untuk usaha melalui bantuan modal yang disalurkan dalam bentuk dana bergulir dan bantuan modal usaha. Dimana dana bergulir ini merupakan pinjaman tanpa ada bunga didalam pengembaliannya dan bantuan modal usaha ialah dana zakat produktif yang diberikan kepada mustahik secara resmi tanpa ada tuntutan dana tersebut dikembalikan.

Pola dari program pendayagunaan melalui dana bergulir ini ialah bergulir dan berkesinambungan. Maksudnya adalah dana yang dipinjamkan mustahik 1 nantinya akan dikembalikan dengan cara diangsur sampai jangka waktu tertentu yang disesuaikan dengan jumlah yang dipinjamkan oleh pihak BAZNAS Kabupaten Padang Lawas.

Dana yang terkumpul dari mustahik 1 kemudian disalurkan kembali kepada mustahik 2 dan begitu seterusnya. Tapi tidak menutup kemungkinan dana yang telah dikembalikan secara penuh oleh mustahik 1 diproduktifkan dengan memberikan kembali kepada mustahik 1 tersebut yang akan dimanfaatkan untuk penambahan modal usahanya lebih lanjut. Namun program ini belum bisa dikatakan efektif karena berbagai kendala yang ditemui. Sebagaimana yang dikatakan oleh ketua BAZNAS Kabupaten Padang Lawas : 
Programnya kurang berhasil karena masih banyak mustahik yang menerima bantuan dana bergulir pengembaliannya tidak lancar bahkan ada yang tidak mengembalikannya, dan tanggung jawab mustahik juga dalam menjalankan usahanya kurang sehingga pendapatannya tidak mengalami peningkkatan.

Permasalahan lain yang ditemukan peneliti di lapangan adalah beberapa mustahik menyalahgunakan dana zakat produktif ini untuk kebutuhan konsumtif. Padalah dana zakat produktif ini diberikan oleh BAZNAS untuk dijadikan modal usaha bukan untuk memenuhi kebutuhan sehari-harinya seperti membayar utang, biaya sekolah dan lain-lain.

\section{Efektivitas Dana Zakat Dalam Peningkatan Pendapatan usaha Mustahik}

Adapun tolak ukur efektivitas suatu program yang analisa dari beberapa indikator sesuai dengan (Budiani, 2007) dengan program pengembangan ekonomi melalui pendisitribusian dan pendayagunaan zakat produktif untuk modal usaha di BAZNAS Kabupaten Padang Lawas yaitu :

\section{Ketepatan Sasaran}

Pada program ini diperuntukkan kepada orang-orang yang memiliki perekonomian lemah sebagaimana hasil wawancara dengan Bendahara BAZNAS Kabupaten Padang Lawas mengatakan bahwa setiap masyarakat fakir dan miskin yang memiliki keterampilan untuk menjalankan sebuah usaha akan tetapi tidak memiliki modal atau peralatan dalam mengembangkan kemampuan dan keterampilannya.

Hal ini dapat dibuktikan dengan hasil wawancara dengan mustahik bahwa sebelum menerima zakat produktif terlebih dahulu harus menyiapkan berkas-berkas untuk mengajukan surat permohonan menerima zakat produktif, seperti poto kopi KTP, Kartu Keluarga, Surat Keterangan Kurang Mampu dan sebelum zakat disalurkan, BAZNAS terlebih dahulu survey kelapangan apakah berkas-berkas yang telah diajukan nyata dilapangan. 
221 | Analisis Efektivitas Dana Zakat dalam Peningkatan Pendapatan Usaha Mustahik di Kabupaten Padang Lawas

\section{Sosialisasi Program}

Proses suatu sosialisasi di BAZNAS kabupaten padang lawas melakukan sosialisasi kepada masyarakat sekitar melalui media sosial, khutbah dimesjid dan di sekolah-sekolah untuk mendukung keberlangsungan dari adanya program-program yang terdapat di BAZNAS kabupaten padang Lawas. Akan tetapi hasil penelitian di lapangan menyatakan bahwa proses sosialisasi dilakukan hanya pada awal pendaftaran itupun hanya sebata cara-cara membuat surat permohonan sebagai penerima zakat produktif, seperti yang dinyatakan oleh para mustahik yang menerima bantua dana zakat produktif sebagai berikut "Kalo sosialisasi saya kurang tau, karena saya mengajukan sendiri kepihak BAZNAS nya saya dikasih tau oleh teman saya kak" wawancara dengan Bapak Sapriadi nasution 30 September 2021)”.

\section{Pemantauan Program}

Sesuatu program yang telah dilaksanakan oleh organisasi, perlu adanya pemantauan yang dapat dilakukan dalam upaya untuk mengetahui peningkatan kualitas mustahik. Pada pematauan progam pihak BAZNAS Kabupaten Padang Lawas bekerja sama dengan pemerintah setempat. Pemantauan dilakukan 1 kali dalam sebulan pada program bantuan modal usaha dan 3 bulan sekali pada bantuan dana bergulir. Namun kenyataannya dilapangan tidak semua usaha dari mustahik zakat produktif di lakukan pemantauan dan pemantauan yang dilakukan tidak rutin tiap bulannya.

\section{Tujuan Program}

Pada tujuan program telah mengusung visi dari memuzakkikan mustahik yang telah mampu menjadi seorang muzakki selain itu adapun tujuan dari BAZNAS kabupaten Padang Lawas ialah dalam penanganan fakir miskin dan meningkatkan usaha atau kualitas hidup si mustahik. Artinya mustahik yang telah menerima bantuan dana zakat produktif telah menerima adanya manfaat dari pemberdayaan ekonomi yang didapatkan dari program-program yang ada di BAZNAS Kabupaten Padang Lawas. Dari hasil pendapatan usahanya tersebut apakah sudah dapat menjadikan mustahik tersebut berubah 
menjadi seorang muzakki. Dari hasil dilapangan didapatkan hasilnya yaitu "kalau sejauh ini pendapatan saya meningkat kak, tapi ya gitu untuk `memenuhi kebutuhan sehari-hari, kalau disuruh untuk berzakat masih belum mampu (wawancara dengan Ibu Samra hasibuan, 1 Oktober 2021)".

Selain itu faktor yang menyebabkan tidak tercapai nya tujuan sebuah program ialah kurangnya tindakan lanjutan setelah pencairan dana bergulir seperti pengawasan, pendampingan serta pembinaan kepada mustahik dari pihak BAZNAS sehingga program ini tidak cukup berhasil.

\section{KESIMPULAN}

Berdasarkan hasil Penelitian peneliti dapat menarik kesimpulan sebagai berikut bahwa Sistem penyaluran dana zakat produktif yang dilakukan di BAZNAS Kabupaten Padang Lawas disalurkan dalam model pemberdayaan ekonomi. Pemberdayaan ekonomi yang dilakukan adalah dengan memberikan bantuan zakat produktif dana bergulir dan bantuan modal usaha. Dana bergulir adalah bantuan modal usaha yang berupa pinjaman sedangkan bantuan modal usaha adalah bantuan modal usaha yang diberikan secara resmi menjadi hak milik mustahik tanpa ada tuntutan untuk mrengembalikan dana tersebut ke BAZNAS. Sistem pendayagunaan zakat produktif yang dilakukan di BAZNAS Kabupaten Padang Lawas ialah digunakan untuk produktif kreatif dengan diberikan bantuan modal usaha. Efektivitas dana zakat dalam peningkatan pendapatan usaha mustahik belum efektif. Sebab, tidak semua mustahik mengalami peningkatan penghasilan pada usahanya. Hal ini dilihat dari tiga indikator yang digunakan yaitu, sosialisasi program, tujuan program dan pemantauan program masih kurang efektif. Sedangkan untuk ketepatan sasaran sudah efektif. 
223 | Analisis Efektivitas Dana Zakat dalam Peningkatan Pendapatan Usaha Mustahik di Kabupaten Padang Lawas

\section{DAFTAR PUSTAKA}

Astuti Hendri Widia, 2019 “Analisis Peranan Zakat Produktif Terhadap Perkembangan Usaha Mustahik (Studi Kasus BMT Assyafi'yah Kotagajah Lampung Tengah),”

Agung Rai I Gusti, 2008 Audit Kinerja Pada Sektor Publik : Konsep, Praktis Studi Kasus Jakarta: Salemba Empat

Evelin Gessy Miranda, 2018 “Analisis Pengaruh Pendyagunaan Zakat Produktif Terhadap Perkembangan Usaha Mikro Mustahik (Studi Kasus BAZNAS)," Universitas Islam Negeri Syarif Hidayatullah

Fakhruddin, 2008 Fiqh Dan Manajemen Zakat Di Indonesia (Malang: UIN Malang Press

Hafhiduddin Didin, 2002 Zakat Dalam Perekonomian Modern (Jakarta: Gema Insani

Hafidhuddin Didin, 2006 Membangun Peradaban Zakat, Meniti Jalan Kegemilangan Zakat Jakarta: Divisi Publikasi Institut Manajemen Zakat

Kementerian Agama RI Direktorat Jenderal Bimbingan Masyarakat Islam Direkotrat Pemberdayaan Zakat 2015, Panduan Organisasi Pengelola Zakat (Jakarta: Kementerian Agama RI

Mawardi, 2010, Zakat Penunjang Ekonomi Islam, Pekanbaru : Alaf Riau

Ningrum, R. T. P. (2016). Penerapan Manajemen Zakat dengan Sistem Revolving Fund Models Sebagai Upaya Efektivitas Penyaluran Zakat Produktif (Studi Pada Lembaga Manajemen Infaq Madiun). El-Wasathiya: Jurnal Studi Agama, Volume 4, Nomer 1, p-ISSN: 2338-9648, e-ISSN: 252

Purhantara, Wahyu (2010) Metode Penelitian Kualitatif Untuk Bisnis Yogyakarta: Graha $\mathrm{Ilmu}$ 
V. Wiratna Sujarweni, 2019, Metode Penelitian Bisnis Dan Ekonomi Yogyakarta: Pustaka Baru Press

Syahreza Mulkan, Pangeran Harahap dan Zainul Fuad, 2019 “Analisis Efektivitas Distribusi Zakat Produktif Dalam Meningkatkan Kesejahteraan Mustahik (Studi Kantor Cabang Rumah Zakat Sumatera Utara),” At-Tawasuth Vol. IV No. 1

Ulfa. Marwiyah, 2019 "Produktifitas Dana Zakat Bagi Mustahik Dalam Peningkatan Usaha (Studi Masyarakat Binaan BAZNAS Kota Makassar),"

Wawancara dengan Ketua BAZNAS Kabupaten Padang Lawas Bapak Drs. H. Abdul Haris padang tanggal 3 Desember 2020

Wawancara dengan Pak Sapriadi Nasution selaku mustahik zakat pada tanggal 30 september 2021

Wawancara dengaan Ibu Samra Hasibuan pada tanggal 1 Oktober 2021

Wawancara dengan Pak Ali Imran pada tanggal 30 september 2021

Wawancara dengan Bapak Muslihuddin selaku Bendahara BAZNAS Kabupaten Padang Lawas. http://jurnal.iain-padangsidimpuan.ac.id/index.php/JISFIM 